\title{
The Study of Chinese Pattern in the View of Historical Materialism of Marxism
}

\author{
Wen Xue \\ Marxism College of CIPL,Beijing 10088
}

\begin{abstract}
Chinese Pattern whose values are rebuilding historical materialism, including concentrated and efficient economic pattern, supplied model political pattern, demanded model social pattern, mixed model culture pattern and harmonious diplomatic pattern. Firstly, Chinese Pattern persevere the combination of uniformity and particularity in the law of historical development. Secondly, the development direction of Chinese Pattern is the combination of economic democracy and political democracy, and it doesn't regard socialism democracy as the accomplishments of capitalism democracy. Finally, Chinese Pattern adhere to the people first values, namely, pursuing the whole development of the society while respecting the individual choices of subject of value. The relative success not only make China develop at a high speed, but also is the new use of the Marxist theory in modern times. It reflect a kind of new thinking, new thought, and new paradigm. Chinese Pattern still needs to persevere the particularity of socialist system in developing.
\end{abstract}

KEY WORDS: Chinese Pattern, Historical Materialism, Prospect

\section{INTRODUCTION}

In 21century, the economy, politics, culture,and diplomatic situation around the world are tending to be plural patterns. Based on their own historical characteristics, different countries have gradually form patterns suit for their development tendency. At present, there are five main development patterns: British and American neo-liberal pattern, Latin American pattern, Europe pattern,East Asian pattern, and Chinese pattern. After the Great Depression in 1930s, America broke up the most serious financial crisis in the summer of 2007. This financial crisis quickly became a serious economic crisis, and fast spreaded into other developed countries and vast developing countries and emerging economies, becoming global financial crisis and economic crisis. This crisis not only heavily attacked the economies, but heavily blew mainstream economic theories and policy views in America and other western countries. At the same time, the employment of socialism got on soundings. Globalization gave the socialism pattern the historic opportunities, while financial crisis gave socialism pattern the second chance of self-inspecting and transition. China made good performance during the financial crisis: The effectiveness of Chinese pattern enhanced influence abroad and deepened cohesion at home . For this reason, what is Chinese pattern, the value and prospect of Chinese pattern become the research priorities for international scholars.

\section{The Characteristic of Chinese Pattern: Five inter-penetrated Patterns}

2.1 Firstly, concentrated and effective economic pattern. To some extend, it is the result of the continuation of Chinese traditional culture over millennia, having caused the central drive pattern of economic pattern. This leading model government is easy to centralize the resource and implement effective actions. Chinese government has a conclusive influence to the economies. The government confirms the direction and goals for priority development and leads the economic structure to fit for the market development. The state political power regulates and controls the macro economy by controlling the 
state-owned enterprises and some closely related national enterprises. The government intensively controls the resources of production, such as important energy and land source. As a result, it guarantees the great power of intervention and action, as well as the infrastructure construction.

2.2 Secondly, supplied model political pattern. Chinese political patterns include political subject, political operation frame, political culture and political decision-making model. Reviewed the development from reforming and opening of China, now the political object is still the government, which is the internal driving force for implementing politicking. The operation of politic is planed and constructed by the government. The political culture is influenced by the continuation of Chinese traditional culture over millennia and radiates from the center to surroundings. The political decision-making model belongs to "supplied model", making and implementing policies. mainly by the government. This kind of political pattern is enough effective but less democratic. So the democratic politics that China plans for a long time is :" the modern people first concept; merits evaluation-emphasied institution for officials selecting ;advanced,selfless, united, governing group; and unique governmental mechanism for division of labor, correcting errors and balance."[1]

2.3 Thirdly, demanded model social pattern. Chinese social pattern is the immediate cause of Chinese political pattern, some scholars think which is formed by four braces:"the elementary units of Chinese society, formed by dispersed and flowing families; the Chinese social network, formed by equal communities and units; the elastic-opening and stereoscopic network, formed by the natural coincide and skeleton interdependency of social and administrative network; the logic of social organizations and public administrations, permeated by family ethical conception. "[2] So it can be said that social network is a specially constituent part of administrative network. In the matter of keeping the exist of Chinese civilly social and administrative network relative uniformity, and maintaining social orders, civilly social network is the significant supplement.

2.4 Fourthly, comprehensive model culture pattern. Chinese culture pattern has its own specific complexity, and having been influenced by thousands of year's history to own a kind of uniformity, containment, and permeability, it will permeate into every aspects of the social development. Viewed from Chinese traditional culture, Chinese culture is mainly made up by three culture:"Taoism, Confucianism ,and Buddhism". Influenced by several millennia traditional culture, as a result,Chinese always think harmony as the core of the culture pattern. With the reforming and opening policy, Chinese culture pattern also absorbed favorable factors of western culture, not excluding foreign culture, owning relatively strong learning ability, and can merge foreign culture and Chinese traditional culture together and permeate into other aspect of social development.

2.5 Fifthly,harmonious diplomatic pattern. Influenced by Chinese traditional culture, China formed a harmony-oriented national quality. So the Chinese diplomatic pattern is a political view of peaceful development and an independent mode of diplomacy. The political view of peaceful development is reflected in the aspects of Chinese new order conception, new security conception, new development conception,etc, while independent mode of diplomacy is reflected in government's diplomatic destination. China always handles its relationship with the world in the way of "golden mean". And "people-oriented and harmony-oriented policy" is not only the core of domestic policy, but also the core of diplomatic policy.

\section{The Value of Chinese Pattern: Re explanation of Historical Materialism}

3.1 The value of Chinese pattern is that it re-explained the historical materialism, which insists on combining the university and particularity of the law of 
historical development. Based on insistence of university, it also emphasizes the logical and experimental particularity of social formation. Marx discussed many times the diversity of socially historical development of human beings in his work < German Ideology>, <The Complete Works of Marx and Engels (XXXI):Manu>and <Preface to Critique of Political Economy>. Marx never agreed with that"turning the summary of original history about western capitalism thoroughly into a theory about philosophy of history in ordinary developing road."[3] Furthermore, he said:"Same economic base-under essential conditioncan have infinitely different empirical facts, natural conditions, race relations, all kinds of historical influence which militates exteriorly, while showing numerous phenomenons of variations and differences in degree. "[4] That is Marxist historical materialism is not technological determinism, whose huge energy is not on single track conception of history, but the sensitivity of historical particularity.

3.2 Chinese pattern, which not only includes economic pattern of seeking for growth in economy and growth in the living standard, but permeated by political pattern and other patterns, comes from fully researching about its own particularity. Chinese pattern is developed in unceasing "test-correction-retest-recorrection".Essentially, it's not only the summary of the process of Chinese social development formerly and currently, but also the planning and expectation of Chinese social development in the future. All aspects that Chinese pattern puts out the inheritance of traditional culture system, as well as the fusion of foreign excellent achievement. The particularity of owe culture and era development promotes the development and innovation. In China's view, social development patterns are various, and not a single pattern is generally appropriate and forever invariable. China has no intention of selling its own development experience to other countries, still further, disagreeing the dissimilation of development patterns . Chinese pattern always initiates mutual reference through communication. The conception of Chinese pattern, which including the social history background of Chinese development road, tradition of national culture ,and foundation of economic theories,etc, is suitable for summarizing the experiences and lessons in Chinese development.

3.3. Chinese pattern does not regard historical materialism as economic determinism. Capitalism established an irrelevance between "economy" and "politic". "Political equality in capitalist democracy and can not only exist with inequality in social economy at same time, but can remain this kind of inequality unchanged."[5] However, the basic changes, made by Marx in capitalist plutonomy, lies in defining the production mode and canon of economics itself by "social factors". Chinese pattern not simply regards economy as "basis", but regards the "reflections"of economic base and "suitable" laws, politics and ideology as "superstructure", thinking they are of different fields. The economy itself is social means that " the conception of 'material' is made up by social relations and practice. Furthermore, productive process and relations are not only 'economic', but also inclusively reflected on laws - the formation and relations of politics and ideology, which can not be put into a spatially isolated superstructure field."[6]

3.4. Chinese pattern resists people first value, not only pursuing social integral development, but respecting the individual choices of the subjects of value as well as human rights and free development of human, which are the two themes of social development of human beings. Marx placed profound hope on the freedom and integrated development of human beings in his works $<$ The Communist Manifesto> and <Capital>.Therefore, he put forward that human beings' situations can only changed by changing the unreasonable social relations in capitalism, establishing communist society, which was the "community of free individuals ". That is " human beings using a comprehensive ways, namely, 
having his or her own comprehensive essence as a whole person."[7] The object of value of Chinese pattern is people's alliance led by working-class, whose goal is to establish a authentic civil society. In capitalist society, "civil society" means devaluation of democracy. "The neo-pluralism in civil society- or the things, starting being called identity politics, did not help us gain more things than statement of general principles and rosy prospects."[8] This kind of society encourages and praises otherness, but not allow ending the relations between rule and oppression."To a great extend,the forcible functions of nation has been replaced by forcible rule in civil society ".[9] Chinese pattern, guided by Scientific Outlook on Development, regards people first as its essence and core, whose goal is to reach an agreement with Marx about thinking of human beings in spiritual pursuing level radically.

\section{The Prospect of Chinese Pattern: Adhering the Particularity of Socialist System}

4.1 The Particularity of Adhering to the Socialist Economic System

4.1.1 In the primary stage of socialism in China, the basic economic system, which not only has connection, but particular or qualitative differences with other economic systems, has its particularity, resulting to be an independent social formation. The economic system in China, whose overall character is reflected in a variety forms of ownership and production mode, regarding public ownership as the main form, controlled its lifelines of the national economy by state-owned business. The properties of economic system, which not only depends on the relationship between labors and ownership, but also the social form, which is combined by labors and means of production, shows the basic difference between socialism and capitalism. Therefore, the adherence to particularity is the adherence to economic democracy, namely, to the occupation and management in means of production of people.
"Firstly, socialist democracy means that it belongs to the democratic self-determination of the producers. It dose not simply distribute 'economic democracy ' more equality, but regards democracy as the regulation and driving mechanism of economy. "[10] Selecting between market and central planning is useless, for they are both not around by the interest of real producers. In the economic and democratic society, the driving force of economy are not from market, but combo of producers."The economic stimuli need not only to be sought from the inside of democratic enterprises, and the interests and goals of spontaneous labors' own, but also to be constructed into all kinds of interaction in enterprises. What we are seeking for is not only the new forms of ownership, but a new dynamic mechanism, rationality and logic."[11]

4.1.2 The adherence to the particularity of socialist economic is the adherence to distributive justice. After the reform and opening-up, the social class structure in China has newly changed and appeared. The particular structure of socialist class: The working-class are divided into productive labors, non-productive labors,mental labors, manual labors, and supervisory and decision-making labors, manual labor, or cross labor of them both. Therefore, the socialism, which is based on eliminating capitalistic class exploitation, should face up to the particularity of this class structure as well as handle the problems of fairness and Justice in every class.

4.2. Adhering to the Particularity of the Socialist Political System

4.2.1 The adherence to the particularity of socialist economic is the adherence to developing a real political democratization. The contraction of fields of economic superpower (such as gender, race, peace, ecology, and democratic civic rights) is the different result of separating capitalistic class exploitation from economic superpower and identity. The capitalistic economy infringed and reduced the fields of economic 
superpower. The fields of social life completely obey the market and the planning of commercialization of production of economic superpower . The right of autonomy of capitalistic policy was reduced. Policy and country was restrained by the demand of particular economy and possessive class more rather than less. The indifference of identity of economic superpower can efficiently and flexibly use the identity of economic superpower as the screen of ideology. In this respect, socialism has at least two tasks. Firstly, reduce the ideology and economic demand, which still can be meet by gender and racial oppression under the socialistic system. Secondly, reevaluate the productions of economic superpower, which are belittled by capitalistic economy.

4.2.2. Political democracy, a political system, which is based on specialized economic and interest relationships, guarantee the equal realization of civic rights. Capitalism replaced democracy all by political democracy. The from of democracy is continuously extending, while its intrinsic value is continuously reducing. Capitalism regards "democratization" as the pronoun of consumer protection doctrine, free market system, and election and reforms of a free and democratic way. Under the circumstance of that capitalism augment the civic rights unprecedentedly for covering the economic inequality, how should socialism treat the democracy is a significant problem. The real democracy is not only shown in the political relationships, but in the economic relationships. Only by the adherence of economic democracy, can the real political democracy come true. Thus,it can give consideration to the varieties and differences of social identity, while reflecting and maintaining the producer's interest, What socialism need is this kind of political system, which acknowledges the varieties and differences, as well as focus on the living quality, culture, environment, and the general interest of "economic superpower" of people. It depends on the country's national condition and real demand that to choose the democratic form. The establishment of political democracy must be based on the clear judgement of national condition. Walking on Chinese democratic road, we must follow the law of the development of democratic politics.

\section{Conclusions}

The conception of Chinese pattern, which including the social history background of Chinese development road, tradition of national culture, and foundation of economic theories, etc, is suitable for summarizing the experiences and lessons in Chinese development. Reduce the ideology and economic demand, which still can be meet by gender and racial oppression under the socialistic system. Secondly, reevaluate the productions of economic superpower, which are belittled by capitalistic economy.

\section{References:}

[1]Hu Jian. Chinese Pattern in Question: Connotation, Characteristic, and Significance[J].Social Sciences,2010,(6).

[2] Pan Wei. Chinese Pattern: Understanding of 60 Years of People's Republic[M]. Central Compilation\&Translation Press ,2009.62.

[3] Anthologies of K.Marx and F-Engels, Book Three [M].Beijing:People's Publishing House,1995.341;342.

[4] Anthologies of K.Marx and F.Engels, Book Twenty-Five [M]. Beijing: People's Publishing House,1979.890.

[5] [6] [8] [9] [10] [11] Alan-Maxons.Wood. Democracy against Capitalism - - Reconstruction of Historical Materialism [M].Chongqing:Chongqing Publishing House,2007.209;60;254;251;287;288.

[7] Collected Works of K.Marx and F-Engels, Book Forty-Two [M].Beijing: People's Publishing House ,1979.123. 